\title{
PENGARUH MODEL PEMBELAJARAN HEURISTIK VEE BERBANTUAN MEDIA VIDEO TERHADAP HASIL BELAJAR IPA DITINJAU DARI MOTIVASI BELAJAR PADA SISWA KELAS VIII SMP
}

\author{
Ni Md Ninda Pradani ${ }^{1}$, I B. Putu Arnyana ${ }^{2}$, I B. Putu Mardana ${ }^{3}$ \\ 1,2,3 Prodi S2 Pendidikan IPA, Jurusan Pendidikan IPA, Fakultas Matematika dan Ilmu \\ Pengetahuan Alam, Universitas Pendidikan Ganesha \\ Singaraja, Indonesia \\ E-mail: ${ }^{1}$ ninda.pradani@ pasca.undiksha.ac.id \\ 2 putu.arnyana@pasca.undiksha.ac.id ${ }^{3}$ putu.mardana@pasca.undiksha.ac.id
}

\begin{abstract}
ABSTRAK
Penelitian ini bertujuan untuk 1) mendeskripsikan dan menjelaskan perbedaan hasil belajar IPA antara siswa yang mengikuti model pembelajar Heuristik Vee berbantuan media video dengan model pembelajaran langsung pada kelas VIII di SMP Negeri 5 Denpasar, 2) mendeskripsikan dan menjelaskan perbedaan hasil belajar IPA antara siswa yang megikuti model pembelajaran Heuristik Vee dengan siswa yang mengikuti model pembelajaran langsung pada kelompok siswa yang memiliki motivasi belajar tinggi, 3) mendeskripsikan dan menjelaskan perbedaan hasil belajar IPA antara siswa yang megikuti model pembelajaran Heuristik Vee dengan siswa yang mengikuti model pembelajaran langsung pada kelompok siswa yang memiliki motivasi belajar rendah. Populasi dalam penelitian ini adalah seluruh siswa kelas VIII SMP Negeri 5 Denpasar yang berjumlah 386, dengan sampel yang berjumlah 64 orang yang diambil secara random. Data hasil belajar dikumpulkan dengan tes hasil belajar, sedangkan data motivasi belajar dikumpulkan dengan kuesioner. Data dianalisis dengan menggunakan analisis ANAVA dua jalur dan dilanjutkan dengan uji Tukey. Hasil penelitian menunjukkan bahwa: (1) Terdapat perbedaan hasil belajar IPA antara siswa yang mengikuti model pembelajaran Heuristik Vee berbantuan media video dengan siswa yang mengikuti model pembelajaran langsung pada siswa kelas VIII di SMP Negeri 5 Denpasar dengan diperoleh nilai signifikansi 0,001 pada "Model" (A) kurang dari 0,05, (2) Terdapat perbedaan hasil belajar IPA antara siswa yang mengikuti model pembelajaran Heuristik Vee berbantuan media video dengan siswa yang mengikuti model pembelajaran langsung pada kelompok siswa yang memiliki motivasi belajar tinggi,dengan diperoleh nilai signfikansi 0,001 kurang dari 0,05 (3) Terdapat perbedaan hasil belajar IPA antara siswa yang mengikuti model pembelajaran Heuristik Vee berbantuan media video dengan siswa yang mengikuti model pembelajaran langsung pada kelompok siswa yang memiliki motivasi belajar rendah, dengan diperoleh nilai signfikansi 0,001 kurang dari 0,05. Adapun implikasi dalam penelitian ini adalah upaya menerapkan model pembelajaran Heuristik Vee berbantuan media video dalam pembelajaran IPA dan upaya menerapkan model pembelajaran langsung dalam pembelajaran IPA dengan memperhatikan motivasi belajar siswa.
\end{abstract}

Kata kunci: hasil belajar IPA, motivasi belajar, model pembelajaran Heuristik Vee berbantuan media video 


\begin{abstract}
This study aims to 1) describe and explain the differences in science learning outcomes between students who follow the Vee Heuristic learning model assisted by video media with direct learning models, in class VIII in SMP Negeri 5 Denpasar, 2) describe and explain differences in science learning outcomes, between students who followed the Vee Heuristic learning model with students who followed the direct learning model in groups of students who had high learning motivation, 3) described and explained the differences in science learning outcomes between students who followed the Vee Heuristic learning model, with students who followed the direct learning model in groups students who have low learning motivation. The population in this study were all students class VIII SMP Negeri 5 Denpasar which amounted to 386, with a sample of 64 people taken at random. Learning outcomes data, collected by learning outcomes test, while learning motivation data collected by questionnaire. Data were analyzed by using two-way ANOVA analysis and continued with Tukey test. The results showed that: (1) there are differences in science learning outcomes among students who followed the Vee Heuristic model assisted by video media, with students who took the direct learning model for eighth grade students in SMP Negeri 5 Denpasar with a significance value of 0.001 in "Model" (A ) less than $0.05,(2)$ There are differences in science learning outcomes, among students who follow the Vee Heuristic learning model assisted by video media, with students who follow the direct learning model in groups of students who have high learning motivation with a signification value of 0.001 less than 0.05 . (3) There are differences in science learning outcomes, between students who joined the Vee Heuristic learning model assisted by video media, and students who took the direct learning model in groups of students who had low learning motivation with a signification value of 0.001 less than 0.05. The implications in this study are efforts to apply the Vee Heuristic learning model assisted by video media in science learning and efforts to apply direct learning models in science learning, by paying attention to student learning motivation.
\end{abstract}

Keywords: learning outcomes of science, learning motivation, learning model of Heuristic Vee assisted video media

\section{PENDAHULUAN}

Sumber daya alam yang melimpah pada suatu Negara belum merupakan jaminan bahwa Negara tersebut akan makmur, jika pendidikan sumber daya manusianya diterlantarkan. Sumber daya manusia (SDM) yang berkualitas sangat dibutuhkan untuk menangani sumber daya alam yang melimpah.

Untuk mewujudkan SDM yang berkualitas harus diiringi dengan peningkatan kualitas pendidikan. Saat ini kualitas pendidikan di Indonesia masih terus berkembang, hal tersebut dapat dilihat dari peran pemerintah untuk menyempurnakan kurikulum agar menjadi lebih efektif dan sesuai dengan karakteristik SDM di Indonesia.

Upaya pemerintah dalam meningkatkan kualitas pendidikan di
Indonesia telah tertuang dalam UndangUndang RI No. 20 tahun 2003, tentang Sistem Pendidikan Nasional Bab II Pasal 3 dinyatakan bahwa, Pendidikan nasional berfungsi mengembangkan kemampuan dan membentuk watak serta peradaban bangsa yang bermartabat dalam rangka mencerdaskan kehidupan bangsa, bertujuan untuk berkembangnya potensi peserta didik agar menjadi manusia yang beriman dan bertakwa kepada Tuhan Yang Maha Esa, berakhlak mulia, sehat, berilmu, cakap, kreatif, mandiri, dan menjadi warga negara yang demokratis serta bertanggung jawab.

Jika upaya pemerintah berhasil dalam meningkatkan kualitas pendidikan di Indonesia, maka bangsa Indonesia akan menjadi bangsa yang cerdas, bermartabat dan secara otomatis kualitas hidup bangsa 
meningkatkan bahkan SDM di Indonesia akan dapat bersaing dalam menghadapi perkembangan globalisasi dan IPTEKS yang semakin berkembang pesat.

Kenyataannya bangsa Indonesia sampai saat ini masih merupakan salah satu negara berkembang dan tertinggal dari negara-negara lainnya di dunia. Dlihat dari segi kualitas pendidikan pun Indonesia masih jauh tertinggal, hal ini dapat dilihat dari laporan UNESCO yang dirilis pada tahun 2012, Indonesia menduduki peringkat 64 dari 120 negara berdasarkan penilaian Education Development Index.

Rendahnya kualitas pendidikan IPA di Indonesia disebabkan karena paradigma pendidikan guru masih pada paradigma pengajaran yang cenderung berupusat pada guru. Dengan demikian guru harus mampu merubah paradigma pendidikan dari paradigma pengajaran tersebut menuju paradigma pembelajaran (Dantes, 2014).

Pergeseran paradigma pengajaran menuju paradigma pembelajaran memunculkan berbagai pengembangan model pembelajaran yang berpusat pada siswa yang menjadikannya suatu pembelajaran inovatif. Pembelajaran inovatif adalah pembelajaran yang berpusat pada siswa (Marhaeni, 2012). Dalam pembelajaran inovatif siswalah yang aktif dalam membangun dan membentuk pengetahuannya. Peran guru hanyalah sebagai fasilitator yang memfasilitasi siswa dalam membangun pengetahuan.

Pemberian mata pelajaran IPA bertujuan untuk membentuk manusia Indonesia seutuhnya sekaligus manusia kerja. Melalui pemberian mata pelajaran IPA, diharapkan dapat meningkatkan kemampuan penalaran pada siswa. Mata pelajaran IPA merupakan mata pelajaran wajib dan berhubungan dengan bagaimana memahami alam secara sistematis melalui proses penemuan dan bukan hanya penguasaan kumpulan pengetahuan yang berupa fakta-fakta, konsep-konsep atau prinsip-prinsip saja (Supriadi \& Sutrisno, 2007). Belajar IPA dapat mengembangkan semua keterampilan yang mereka miliki secara sistematis, jujur dan disiplin. Oleh sebab itu, siswa sebagai calon generasi penerus, harus dibekali pengetahuan tersebut melalui kegiatan pembelajaran di sekolah.

Guru menyediakan kegiatan-kegiatan yang merangsang keingintahuan siswa dan membantu mereka untuk mengekspresikan gagasan-gagasannya dan mengekspresikan ide ilmiah mereka. Menyediakan sarana yang merangsang siswa berfikir secara produktif dan menyediakan kesempatan dan pengalaman yang paling mendukung proses belajar siswa, tentunya akan membangun motivasi siswa dalam kegiatan pembelajaran (Watts dan Pope dalam Suparno, 1997).

Jika guru sudah mampu menerapkan suatu model pembelajaran sesuai dengan tahapan dan karakteristiknya, maka seharusnya dapat membantu siswa dalam memahami suatu materi sehingga dapat mencapai suatu hasil belajar yang optimal. Hasil belajar merupakan perubahan siswa dari segi kognitif, afektif maupun psikomotorik setelah melakukan proses belajar (Susanto, 2013). Hasil belajar dapat digunakan siswa untuk mengetahui ketercapaian mengenai materi yang telah dibahas. Hasil belajar juga dipergunakan oleh guru untuk mengetahui keberhasilannya dalam mengajar dengan menerapkan suatu metode dan model pembelajaran. Hasil belajar tersebut digunakan guru sebagai bahan evaluasi untuk memperbaiki ataupun meningkatkan cara mengajarnya.

Dalam pencapaian suatu hasil belajar sangat dipengaruhi oleh berbagi faktor. Menurut Wasliman (dalam Susanto, 2013), faktor-faktor yang dapat memengaruhi hasil belajar siswa tersebut meliputi factor internal dan eksternal. Faktor internal (yang berasal dari dalam diri siswa) meliputi: kecerdasan, minat dan perhatian, motivasi belajar, ketekunan, sikap, kebiasaan belajar, serta kondisi fisik dan kesehatan. Selain itu adapun faktor eksternal (lingkungan siswa) yang dapat memengaruhi hasil belajar siswa meliputi: keluarga, sekolah dan masyarakat. Faktor-faktor tersebut perlu diperhatikan oleh guru maupun orang tua siswa untuk membimbing siswa dalam mencapai hasil belajar yang positif.

Pada kenyatannya, berdasarkan hasil studi dokumen (pencatatan dokumen) yang dilakukan di SMP N 5 Denpasar, ditemukan 
bahwa, hasil belajar IPA siswa kelas VIII di SMP Negeri 5 Denpasar masih tergolong rendah. Hal ini dapat dibuktikan dari hasil ulangan umum mata pelajaran IPA siswa kelas VIII semester I tahun pelajaran 2017/2018 tergolong rendah dan bahkan ada yang dibawah KKM (Kriteria Ketuntasan Minimal) yang di tetapkan masing-masing sekolah. Berikut nilai hasil ulangan umum IPA siswa kelas VIII semester I tahun pelajaran 2017/2018 di SMP Negeri 5 Denpasar diuraikan sebagai berikut. nilai rata-rata kelas VIII A sebesar 68,18 , nilai rata-rata kelas VIII B sebesar 66,00, nilai rata-rata kelas VIII $C$ sebesar 66,40 , nilai rata-rata kelas VIII D sebesar 68,06 , nilai rata-rata kelas VIII E sebesar 67,11, nilai rata-rata kelas VIII $F$ sebesar 65,85 , nilai rata-rata kelas VIII G sebesar 67,32 , nilai rata-rata kelas VIII $\mathrm{H}$ sebesar 68,97 , nilai rata-rata kelas VIII I sebesar 67,06, nilai rata-rata kelas VIII $\mathrm{J}$ sebesar 65,64 , nilai rata-rata kelas VIII $\mathrm{K}$ sebesar 69,26 dengan kriteria ketuntasan minimal sebesar 68,00.

Berdasarkan observasi dan wawancara kepada guru-guru yang mengajar di SMP Negeri 5 Denpasar, di duga penyebab hasil belajar IPA siswa kelas VIII di SMP Negeri 5 Denpasar yang masih tergolong rendah seperti uraian diatas tersebut adalah, (1) proses pembelajaran masih terpusat pada guru, artinya guru yang lebih banyak memberikan informasi dalam pembelajaran, sehingga keterlibatan siswa menjadi kurang (2) guru belum menerapkan teknik-teknik presentasi dan demonstrasi yang efektif (3) kurangnya aktifitas siswa dalam belajar melalui prosedur penemuan, artinya dalam hal ini siswa masih bergantung pada bimbingan dan demonstrasi dari guru dan (4) kurangnya penggunaan media pembelajaran yang menarik, karena guru hanya menggunakan media yang sudah tersedia di sekolah, jika medianya tidak tersedia mengenai materi yang dibahas, maka guru mengajar tanpa menggunakan media pembelajaran.

Berdasarkan permasalahan tersebut, perlu adanya penerapan model pembelajaran yang inovatif dalam proses pembelajaran IPA kelas VIII di SMP Negeri 5 Denpasar. Salah satu model pembelajaran yang dapat diterapkan adalah model pembelajaran Heuristik Vee berbantuan media video.

Model Pembelajaran Heuristik Vee merupakan cara pemecahan masalah dengan menggunakan prosedur-prosedur penemuan dalam ilmu pengetahuan alam yang dituangkan dalam diagram "V" (Suastra, 2009). Model pembelajaran ini dikembangkan oleh Gowin sejak tahun 1977 sebagai suatu model untuk membantu siswa dalam memahami struktur pengetahuan dan proses bagaimana pengetahuan dikonstruksi (Suastra, 2009).

Terdapat lima tahapan dalam menerapakan model pembelajaran Heuristik Vee. Tahapan tersebut yaitu (1) orientasi, (2) pengungkapan gagasan awal siswa, (3) fokus penyelidikan, (4) pengkonstruksian pengetahuan baru, dan (5) evaluasi (Suastra, 2009).

Dalam menerapkan model pembelajaran Heuristik Vee sebaiknya dibantu dengan menggunakan media pembelajaran. Dalam penelitian ini, digunakan media video sebagai penunjang dalam menerapkan model pembelajaran Heuristik Vee. Media video dalam pembelajaran merupakan media yang memiliki unsur suara (audio) dan juga unsur gambar (visual) untuk membantu menjelaskan materi yang dibahas. Media video pembelajaran merupakan media yang digunakan untuk merangsang pikiran, perasaan dan kemauan siswa untuk belajar melalui penayangan ide atau gagasan, pesan dan informasi secara audio visual (Mahadewi, dkk., 2006).

Media video dapat diintegrasikan dalam model pembelajaran Heuristik Vee pada tahap ke tiga yaitu, fokus penyelidikan. Pada tahap itu siswa akan ditayangkan video mengenai topik yang dibahas, kemudian siswa akan diberikan pertanyaan kunci yang berkaitan dengan topik.

Motivasi adalah perubahan energi dalam diri seseorang yang ditandai dengan munculnya feeling dan didahului dengan tanggapan terhadap adanya tujuan. Berdasarkan pengertian yang dikemukakan oleh Mc. Donald ini mengadung tiga elemen penting, sebagai berikut: (1) motivasi mengawali terjadinya perubahan energi pada 
diri setiap individu manusia. Karena menyangkut perubahan energi manusia, penampakannya akan menyangkut kegiatan fisik manusia, (2) motivasi ditandai dengan munculnya rasa/feeling, afeksi seseorang . Motivasi relevan dengan persoalanpersoalan kejiwaan, afeksi dan emosi yang dapat menentukan tingkah laku manusia, (3) motivasi akan dirangsang karena adanya tujuan. Motivasi memang muncul dari dalam diri manusia, tetapi kemunculannya karena terangsang/ terdorong oleh adanya unsur lain. Dalam hal ini adalah tujuan menyangkut dalam hal kebutuhan (Mc. Donald dalam Hamalik, 2011: 158). Mengacu pada pemaparan di atas, maka judul penelitian ini adalah Pengaruh Model Pembelajaran Heuristik Vee berbantuan media video terhadap Hasil Belajar IPA Ditinjau dari Motivasi Belajar Siswa Kelas VIII di SMP Negeri 5 Denpasar Tahun Pelajaran 2017/2018.

\section{METODE PENELITIAN}

Jenis penelitian ini adalah eksperimen semu/quasi eksperiment. Rancangan eksperimen yang digunakan dalam penelitian adalah the posttest only control group design. Rancangan the posttest only control group design dipadukan dengan rancangan faktorial $2 \times 2$. Pada analisis faktorial $2 \times 2$, perlakuan disusun sedemikian rupa sehingga setiap individu dapat menjadi subjek secara besamaan dalam dua faktor yang berbeda, yang setiap faktornya terdiri atas beberapa level (Dantes, 2012).
Populasi dalam penelitian ini adalah siswa kelas VIII yang ada di SMP Negeri 5 Denpasar 20170 2018. Teknik pemilihan sampel dalam penelitian ini adalah menggunakan random sampling. Hal tersebut karena pengambilan sampel dialakukan secara acak tanpa memerhatikan strata yang ada dalam populasi itu.

Kelas yang dipilih menjadi sampel adalah kelas VIII A, B, C dan D di SMP Negeri 5 Denpasar. Setelah itu, dilakukan pengundian lagi untuk menentukan kelas yang sebagai kelompok ekperimen dan yang sebagai kelompok kontrol. Setelah dilakukan pengundian dapat ditentukan bahwa kelas yang muncul sebagai kelompok eksperimen adalah Kelas VIII B dan kelas VIII C yang terdiri dari 71 siswa. Kelas yang muncul sebagai kelompok kontrol adalah kelas VIII A dan VIII D yang terdiri dari 67 siswa.

Metode pengumpulan data yang digunakan adalah tes. Hasil belajar IPA siswa diukur dengan tes hasil belajar. Motivasi belajar siswa diukur dengan kuesioner.

\section{HASIL DAN PEMBAHASAN \\ Hasil Penelitian}

Data hasil penelitian disajikan dalam deskripsi data yang terdiri dari delapan kelompok disribusi. Adapun rekapitulasi keterampilan hasil belajar IPA ke enam kelompok tersebut dapat dilihat pada tabel 1 berikut ini.

Tabel 1 Rekapitulasiasil Perhitungan Nilai Hasil Belajar IPA

\begin{tabular}{lllllll}
\hline & \multicolumn{6}{c}{ Data } \\
\cline { 2 - 7 } Statistik & $\mathbf{A 1}$ & $\mathbf{A 2}$ & $\mathbf{A 1 B 1}$ & $\mathbf{A 1 B 2}$ & $\mathbf{A 2 B 1}$ & $\mathbf{A 2 B 2}$ \\
\hline Mean & 76,65 & 67,76 & 85,13 & 68,17 & 59,61 & 75,91 \\
Median & 77 & 69 & 86 & 69 & 60 & 77 \\
Modus & 69 & 60 & 77 & 69 & 60 & 25 \\
Standar Deviasi & 9,80 & 9,34 & 5,56 & 3,93 & 4,46 & 4,44 \\
Varians & 96,14 & 87,30 & 30,94 & 15,42 & 19,88 & 19,72 \\
Nilai Maximum & 94 & 83 & 94 & 77 & 69 & 83 \\
Nilai Minimum & 63 & 54 & 77 & 63 & 54 & 69 \\
Rentangan & 31 & 29 & 17 & 14 & 15 & 14 \\
\hline
\end{tabular}


Sebelum dilaksanakan uji hipotesis, terlebih dahulu dilakukan uji prasyarat meliputi uji normalitas sebaran data dan uji homogenitas varians. Uji prasyarat perlu dilakukan untuk menyakinkan bahwa uji statistik yang digunakan dalam pengujian benar-benar dapat dilakukan. Uji normalitas sebaran data dalam penelitian ini dilakukan dengan menggunakan KolmogorovSmirnov. Adapun hasil perhitungan secara keseluruhan dapat dilihat pada Tabel 2 berikut.

Tabel 2. Ringkasan Uji Normalitas Kelompok Data

\begin{tabular}{|c|c|c|c|}
\hline Kelompok & Statistik & Kolmogorov-Smirnov (Sig.) & Keterangan \\
\hline A1 & 0,197 & 0,200 & Normal \\
\hline $\mathrm{A} 2$ & 0,186 & 0,128 & Normal \\
\hline $\mathrm{A} 1 \mathrm{~B} 1$ & 0,196 & 0,200 & Normal \\
\hline $\mathrm{A} 1 \mathrm{~B} 2$ & 0,197 & 0,200 & Normal \\
\hline A2B1 & 0,186 & 0,128 & Normal \\
\hline $\mathrm{A} 2 \mathrm{~B} 2$ & 0,198 & 0,200 & Normal \\
\hline
\end{tabular}

Berdasarkan penyajian data pada Tabel 2, dapat dilihat bahwa nilai signifikansi semua kelompok data lebih

besar dari 0,05. Dengan demikian dapat disimpulkan bahwa semua kelompok data berdistribusi normal.

Uji homogenitas varians dimaksudkan untuk memperlihatkan bahwa dua atau lebih kelompok data sampel berasal dari populasi yang memiliki varians sama atau homogen. Pengujian ini dilakukan dengan menggunakan uji kesamaan varians-kovarian melalui uji Levene's. Uji homogenitas secara terpisah dilakukan dengan uji Levene's menunjukan kelompok data hasil belajar IPA diperoleh nilai $F$ sebesar 0,096 dengan signifikansi 0,757 , maka secara statistik dapat disimpulkan bahwa semua data nilai hasil belajar IPA siswa memiliki varians yang homogen karena nilai signifikansinya lebih besar dari 0,05. Uji Levene'skelompok data motivasi belajardiperoleh nilai $\mathrm{F}$ sebesar 1,830 dengan signifikansi 0,179 maka secara statistik dapat disimpulkan bahwa semua data nilai motivasi belajar siswa memiliki varians yang homogen karena nilai signifikansinya lebih dari 0,05 . Dengan demikian secara statistik dapat disimpulkan bahwa semua data skor data hasil belajar IPA dan motivasi belajar siswa memiliki varians yang homogen karena nilai signifikansinya lebih besar dari 0,05 sehingga ANAVA dua jalan dapat dilanjutkan.

Pengujian selanjutnya yang dilakukan adalah pengujian hipotesis dengan menggunakan anava dua jalur. Ringkasan pengujian hipotesis dapat dilihat pada tabel 3 berikut.

Tabel 3 Ringksasan ANAVA Dua Jalan Hasil Belajar IPA

\begin{tabular}{lllllc}
\hline \multicolumn{1}{c}{ Sumber Variasi } & \multicolumn{1}{c}{ JK } & \multicolumn{1}{c}{ df } & \multicolumn{1}{c}{ RJK } & \multicolumn{1}{c}{ F } & \multicolumn{1}{c}{ Sig. } \\
\hline Intercept & 479667,924 & 1 & 479667,924 & 22319,368 & 0,001 \\
Model*Motivasi Belajar & 6361,141 & 1 & 6361,141 & 295,989 & 0,001 \\
Dalam & 1891,217 & 88 & 21,491 & & \\
Total & 489741,000 & 92 & & & \\
\hline
\end{tabular}


Hasil uji hipotesis pertama berdasarkan Tabel 3 di atas, diperoleh niai signifikansi sebesar $0,001<0,05$. Hal tersebut menunjukkan bahwa terdapat perbedaan yang signifikan hasil belajar IPA antara siswa yang mengikuti model pembelajaran Heuristik Vee berbantuan media video

dengan siswa yang mengikuti mode pembelajaran langsung.

Hasil belajar IPA siswa yang mengikuti model pembelajaran Heuristik Vee berbantuan media video lebih unggul dibandingkan dengan kelompok siswa yang mengikuti model pembelajaran langsung.

Hal ini sejalan dengan pendapatnya Senjawati (2014) yang menyatakan bahwa, model pembelajaran Heuristik Vee adalah model pembelajaran yang mengarah pada peserta didik mencari dan menemukan sendiri fakta, prinsip, dan konsep atau ide yang mereka butuhkan dan memberikan penjelasan bahwa pengetahuan baru dapat dikonstruksi melalui penyelesaian dari sebuah permasalahan yang berkaitan dengan pengetahuan tersebut.

Siswa menemukan suatu konsep tersebut melalui suatu percobaan dan diakhir pembelajaran siswa dituntut untuk mengisi diagram Vee untuk menghubungkan atau mengaitkan antara pengetahuan awal yang dimiliki dengan klaim suatu nilai pengetahuan setelah melakukan suatu percobaan. Hal ini sangat berpengaruh positif untuk membantu siswa memperoleh suatu pembelajaran yang bermakna.

\section{Pembahasan}

Pembelajaran dengan model pembelajaran Heuristik Vee lebih efektif jika dibantu dengan media video pembelajaran. Hal tersebut karena dengan media video dapat menarik perhatian siswa dalam mengikuti pembelajaran dengan baik. Selain itu, yang terpenting dalam penggunaan media video pembelajaran adalah untuk membantu siswa memahami suatu konsep yang abstrak agar menjadi lebih konkrit. Hal ini sejalan dengan pendapatnya Ibrahim dkk. dalam Tegeh, (2008) yang menyatakan bahwa, media pembelajaran adalah segala sesuatu yang dapat digunakan untuk menyalurkan pesan (bahan pembelajaran) sehingga dapat merangsang perhatian, minat, pikiran, dan perasaan pebelajar (siswa) dalam kegiatan belajar untuk mencapai tujuan pembelajaran tertentu. Penelitian yang dilakukan oleh Mutai (2015) juga menunjukkan peningkatan yang signifikan pada pemahaman konseptual dan metakognisi siswa dalam topik fisika

Selanjutnya pengujian hipotesis kedua dilakukan dengan menggunakan uji Tukey yang dibantu dengan menggunakan SPSS 20.0 for windows diperoleh nilai signfikansi $0,001<0,050$. Selain itu juga diperoleh nilai $\mathrm{t}_{\text {hitung }}=6,430$ dan $\mathrm{t}_{\text {tabel }}=2,86$ pada taraf signifikansi 0,05 . Hal ini berarti $t_{\text {hitung }}>t_{\text {tabel }}$ yang artinya hipotesis nol ditolak dan hipotesis alternatif diterima. Dengan demikian dapat disimpulkan bahwa, terdapat perbedaan hasil belajar IPA antara siswa yang mengikuti model pembelajaran Heuristik Veeberbantuan media videodengan siswa yang mengikuti model pembelajaran langsung pada kelompok siswa yang memiliki motivasi belajar tinggi.

Perbedaan hasil belajar IPA tersebut dipengaruhi oleh faktor eksternal berupa model pembelajaran yang diberikan berbeda. Perbedaan penerapan model pembelajaran yang diterapkan kepada siswa yang memiliki motivasi belajar tinggi berpengaruh pada hasil belajar siswa. Motivasi sebagai suatu kekuatan yang mampu mengubah energi dalam diri seseorang dalam bentuk aktivitas nyata untuk mencapai tujuan tertentu (Aunurrahman, 2011). Motivasi di dalam kegiatan belajar merupakan kekuatan yang dapat menjadi tenaga pendorong bagi siswa 
untuk mendayagunakan potensi-potensi yang ada pada dirinya dan potensi di luar dirinya untuk mewujudkan tujuan belajar. Siswa yang memiliki motivasi belajar nampak melalui kesungguhan untuk terlibat dalam proses belajar, antara lain nampak melalui keaktifan bertanya, mengemukakan pendapat, menyimpulkan pelajaran, mencatat, membuat resume, mempraktekan sesuatu, mengerjakan latihan-latihan dan evaluasi sesuai dengan tuntutan pembelajaran. Sebaliknya siswa-siswa yang tidak atau kurang memiliki motivasi belajar, umumnya kurang mampu bertahan untuk belajar lebih lama, kurang bersungguhsungguh dalam mengerjakan tugas. Sikap yang kurang positif ini semakin nampak ketika tidak ada orang lain (guru, orang tua) yang mengawasinya.

Siswa yang memiliki motivasi belajar tinggi perlu difasilitasi dengan model pembelajaran yang dapat memperkuat dorongan dalam dirinya untuk mencapai hasil belajar yang optimal. Model pembelajaran yang cocok digunakan adalah model pembelejaran Heuristik Veeberbantuan media video. Salim (dalam Suastra, 2009:127), menyatakan bahwa,"Heuristik merupakan suatu cara yang dipakai untuk memecahkan masalah dengan menggunakan prosedur-prosedur penemuan dalam ilmu pengetahuan", sedangkan vee dalam Heuristik Vee merupakan diagram yang berbentuk "V". Diagram vee digunakan untuk melihat hubungan antara apa yang telah diketahui dan pengetahuan baru yang akan dihasilkan serta mencoba memahaminya (Dahar, 2006:112). Jadi Heuristik Vee dapat diartikan sebagai cara memecahakan masalah dengan menggunakan prosedurprosedur penemuan dalam ilmu pengetahuan alam yang dituangkan dalam diagram "V".

Hasil penelitian Hamdu (2011) mendukung hasil penelitian ini yang menyatakan bahwa, motivasi belajar dengan prestasi belajar siswa memiliki pengaruh yang signifikan, dengan demikian dapat disimpulkan bahwa terdapat pengaruh motivasi belajar terhadap prestasi belajar IPA. Setelah dikorelasikan menunjukkan interprestasi tingkat reliabilitas tinggi besarnya pengaruh motivasi belajar terhadap prestasi belajar IPA siswa kelas IV SDN Tarumanagara Tawang Tasikmalaya adalah sebesar 48,1\%. Hasil penelitiannya Feronita, dkk. (2018) menyatakan bahwa ada hubungan yang positif dan signifikan antara motivasi belajar dengan hasil belajar matematika siswa. Artinya semakin tinggi motivasi belajar maka semakin tinggi hasil belajar matematika yang diperoleh. Sebaliknya apabila semakin rendah motivasi belajar maka semakin rendah juga hasil belajar matematika yang diperoleh.

Siswa yang memiliki motivasi belajar tinggi, jika tidak difasilitasi untuk belajar dengan prosedur-prosedur penemuan dapat berpengaruh negatif terhadap hasil belajar siswa. Hal tersebut karena siswa tidak dituntut berbuat untuk melakukan sesuatu hingga menemukan sendiri pengetahuannya. Siswa yang mempunyai motivasi belajar tinggi cenderung memiliki rasa ingin tahu dan keaktifan belajar yang tinggi. Sesuai dengan karakteristik siswa yang memiliki motivasi belajar tinggi tersebut, jika siswa dibelajarkan dengan model pembelajaran langsung yang lebih dominan kegiatan ceramah, tanya jawab dan penugasan maka dapat berpengaruh negatif terhadap hasil belajar siswa. Hal tersebut karena siswa cepat bosan dengan pembelajaran yang monoton, padahal motivasi belajarnya tinggi, karena itu siswa tidak mengerahkan unsur-unsur motivasi belajarnya yang tinggi dalam megikuti pembelajaran di kelas.

Uji lanjut yang digunakan untuk menguji hipotesis empat ini adalah menggunakan ujiTukey. diperoleh nilai 
signfikansi $0,001<0,05$. Selain itu, diperoleh nilai $\mathrm{t}_{\text {hitung }}=6,036$ dan $\mathrm{t}_{\text {tabel }}=$ 2,86 pada taraf signifikansi 0,05 . Hal ini menunjukkan bahwa $\mathrm{t}$ hitung $>\mathrm{t}$ tabel, yang artinya hipotesis nol ditolak dan hipotesis alternatif diterima. Dengan demikian dapat disimpulkan bahwa, terdapat perbedaan hasil belajar IPA antara siswa yang mengikuti model pembelajaran Heuristik Vee berbantuan media videodengan siswa yang mengikuti model pembelajaran langsung pada kelompok siswa yang memiliki motivasi belajar rendah.

Siswa yang memiliki motivasi belajar rendah tidak dapat mengkuti dengan baik pembelajaran yang berdasar pada prosedur-prosedur penemuan seperti yang ada dalam model pembelajaran Heuristik Vee. Hal tersebut karena siswa tidak mau aktif untuk menggali suatu pengetahuan melalui prosedur-prosedur penemuan. Siswa cenderung pasif dalam mengikuti proses pembelajaran. Siswa juga memiliki rasa ingin tahu yang rendah, sehingga siswa tidak aktif untuk menggai suatu pengetahuan dari berbagai sumber. Dengan demikian, siswa yang memiliki motivasi belajar rendah jika dibelajarkan dengan model pembelajaran Heuristik Vee berbantuan media video berpengaruh negatif terhadap hasil belajar IPA siswa.

Siswa yang memiliki karakteristik motivasi belajar rendah yaitu memiliki rasa inggin tahu yang rendah, kurang aktif dalam mengikuti pembelajaran dan memiliki dorongan yang lemah untuk mencapai hasil belajar yang optimal. Karakteristik siswa seperti itu lebih cocok dibelajarkan dengan model pembelajaran yang mendominasi kegiatan ceramah, tanya jawab dan penugasan atau lebih dikenal dengan pembelajaran langsung. Hal tersebut karena siswa yang memiliki motivasi belajar rendah cenderung pasif, siswa tersebut hanya mendengarkan materi yang disampaikan oleh guru. Siswa yang mengikuti model pembelajaran langsung sejatinya memiliki pengetahuan yang terbatas, hal tersebut sebatas materi yang hanya disampaikan oleh guru. Selain itu, salah satu karakteristik siswa yang memiliki motivasi belajar rendah adalah memiliki rasa ingin tahu yang rendah. Siswa yang memiliki motivasi belajar rendah merasa lebih nyaman dibelajarakan dengan model pembelajaran langsung. Hal tersebut karena siswa tidak begitu dituntut untuk menemkan suatu pengetahuan melalui prosedur-prosedur penemuan. Siswa juga tidak dituntut untuk secara mandiri mencari materi yang dipelajari dari berbagai sumber. Karena kenyamanan siswa dan cara guru menyampaikan materi secara lisan yang baik dan mencangkup semua materi yang dipelajari dapat berpengaruh positif terhadap hasil belajar IPA siswa yang memiliki motivasi belajar rendah.

Model pembelajaran langsung adalah model pembelajaran yang menekankan pada penguasaan konsep dan/atau perubahan perilaku dengan mengutamakan pendekatan deduktif, dengan ciri-ciri sebagai berikut: (1) transformasi dan ketrampilan secara langsung; (2) pembelajaran berorientasi pada tujuan tertentu; (3) materi pembelajaran yang telah terstuktur; (4) lingkungan belajar yang telah terstruktur; dan (5) distruktur oleh guru. Guru berperan sebagai penyampai informasi, dan dalam hal ini guru seyogyanya menggunakan berbagai media yang sesuai, misalnya film, tape recorder, gambar, peragaan, dan sebaganya..

Siswa yang memiliki motivasi belajar rendah merasa lebih nyaman mengikuti pembelajaran yang bersifat langsung, hal tersebut karena siswa tidak begitu dituntut untuk aktif berdiskusi dan berpikir secara kritis untuk memecahkan permasalahan yang diberikan oleh guru. Hal tersebut berdampak pada hasil belajarnya, meskipun tidak mencapai hasil belajar yang optimal, setidaknya hasil belajar IPA antara siswa yang mengikuti model pembelajaran langsung lebih baik daripada hasil belajar IPA siswa yang mengikuti model pembelajaran Heuristik Vee berbantuan media video.

\section{SIMPULAN DAN SARAN}


Berdasarkan hasil pengujian hipotesis yang telah dipaparkan pada bagian sebelumnya, maka dapat diambil beberapa simpulan dalam penelitian ini adalah sebagai berikut. (1) Terdapat perbedaan hasil belajar IPA antara siswa yang mengikuti model pembelajaran Heuristik Vee berbantuan media videodengan siswa yang mengikuti model pembelajaran langsung pada siswa kelas VIII di SMP Negeri 5 Denpasar dengan diperoleh nilai signifikansi 0,001 pada "Model" (A) kurang dari 0,05, (2) Terdapat perbedaan hasil belajar IPA antara siswa yang mengikuti model pembelajaran Heuristik Vee berbantuan media videodengan siswa yang mengikuti model pembelajaran langsung pada kelompok siswa yang memiliki motivasi belajar tinggi,dengan diperoleh nilai signfikansi 0,001 kurang dari 0,05 (3) Terdapat perbedaan hasil belajar IPA antara siswa yang mengikuti model pembelajaran Heuristik Vee berbantuan media videodengan siswa yang mengikuti model pembelajaran langsung pada kelompok siswa yang memiliki motivasi belajar rendah, dengan diperoleh nilai signfikansi 0,001 kurang dari 0,05.

Berdasarkan beberapa temuan yang diperoleh dari penelitian ini, dan dengan mempertimbangkan implikasi penelitian seperti yang telah diuraikan di atas, maka ada beberapa saran yang dapat dikemukakan adalah sebagai berikut. (1) Kepada siswa hendaknya selalu mengembangkan potensi akademik yang dimiliki untuk mencapai keberhasilan dalam belajar. (2) Kepada guru: (1) Model pembelajaran Heuristik Vee berbantuan media video dapat dijadikan salah satu alternatif dalam penerapan model pembelajaran di kelas; (2) Agar pembelajaran efektif, maka model pembelajaran yang diterapkan harus mempertimbangkan motivasi belajar yang dimiliki siswa, jika siswa memiliki motivasi belajar tinggi maka model pembelajaran Heuristik Vee berbantuan media video efektif untuk diterapkan. Jika siswa memiliki motivasi belajar rendah, maka model pembelajaran langsung lebih efektif untuk diterapkan. Dengan demikian kombinasi model pembelajaran sangat menentukan hasil belajar IPA siswa (3) Kepada pihak sekolah, khususnya kepala sekolah/instansi diarankan untuk dapat mengeluarkan kebijakan yang berkaitan dengan pengembangan model pembelajaran yang mengarah pada pola pembelajaran kooperatif. (4) Melihat keterbatasan waktu dan pokok bahasan yang digunakan dalam penelitian ini, maka disarankan bagi peneliti lain agar melaksanakan penelitian sejenis dengan pemilihan materi yang berbeda dan waktu yang lebih lama untuk mendapatkan gambaran yang lebih meyakinkan mengenai pengaruh model pembelajaran Heuristik Vee berbantuan media video terhadap hasil belajar IPA ditinjau dari motivasi belajar siswa. Dalam penelitian ini variabelnya juga dapat dikembangkan sehingga nantinya dapat memperoleh hasil pembelajaran yang lebih baik. (5) Adapun keunggulan dalam model pembelajaran yang digunakan dalam penelitian ini daintaranya (1) dapat memberikan pengalaman bagi siswa dalam melakuakan suatu percobaan di laboratorium, (2) pembelajaran menjadi lebih bermakna karena siswa yang langsung menemukan pengetahuannya melalui percobaan, (3) siswa aktif dalam memecahkan masalah dan mengkonstruksikan pengetahuan barunya, (4) siswa memperoleh kebebasan dalam menyampaikan pengungkapan gagasannya dan bertukar pikiran dengan kelompoknya, (5) keterampilan yang di dapat siswa diperoleh berdasarkan pemahaman bukan latihan dan penilaian dengan berbagai cara. (6) Selain beberapa keunggulan diatas, model pembelajaran Heuristik Vee juga 
memiliki kelemahan. Kelemahan-kelemahan model pembelajaran Heuristik Vee adalah sebagai berikut. (1) resiko pembelajaran di laboratorium bisa berbahaya, jika siswa tidak teliti dan tidak mengikuti tata tertib, (2) biaya yang diperlukan lebih banyak untuk melengkapi sesuai dengan penelitian yang dilakukan.

Dalam penelitian ini variabelnya juga dapat dikembangkan sehingga nantinya dapat memperoleh hasil pembelajaran yang lebih baik.

\section{DAFTAR RUJUKAN}

Aunurrahman. 2011. Belajar dan Pembelajaran. Bandung: Alfabeta

Dahar, R. W. 2006. Teori-teori Belajar \& Pembelajaran. Jakarta: Erlangga.

Dananjaya, IG. A. B. Suastra, I.W. \& A.A.I.A.R. Sudiatmika. 2016. Penerapan Model Quantum Learning Berbantuan Media Video sebagai Upaya Meningkatkan Motivasi dan Hasil Belajar Siswa. Jurnal Wahana Matematika dan Sains.Vol. 9, No. 2, Oktober 2016.

Dantes, N. 2010. Analisis Varian. Singaraja: Undiksha.

Feronita, Y. L. Oktariani, S. \& Sri Adi Widodo. Hubungan antara Kenakalan Remaja, Minat Belajar dan Motivasi Belajar dengan Hasil Belajar Matematika Siswa. Prosiding Seminar Nasional Etnomatnesia. T.t.http://jurnal.ustjogja.ac.id/index.ph p/etnomatnesia/article/view/2400/1361 .pdf (Diakses 18 Maret 2017).

Hamalik, O. 2011. Proses Belajar Mengajar. Jakarta: Bumi Aksara

Mahadewi, LPP. Tastra, IDK. \& I K. Sudarma. 2006. Media Video Pembelajaran. Singaraja: Jurusan Teknologi Pendidikan, FIP, Undiksha.
Senjawati, E. 2014. Prosding Seminar Nasional Pendidikan Matematika. Perbandingan Pemahaman Matematik Siswa yang Pembelajarannya Menggunakan model Pembelajaran Heuristik Vee dengan yang Menggunakan Cara Biasa (hlm. 334341). Bandung: Program Pasca Sarjana STKIP.

Suastra, I. W. 2009. Pembelajaran Sains Terkini. Singaraja: Undiksha.

Suparno, P. 1997. Filsafat Konstruktivisme dalam Pendidikan. Yogyakarta: Kanisius.

Supriadi, D. \& Sutrisno. 2007. Ilmu Pengetahuan Alam (Studi dan Pengajaran). Bogor: Yudistira.

Suryandari. S., Widha \& Suparmi. 2016. Pengembangan Media Pembelajaran Menggunakan Video Dokumenter Berbasis Inkuiri Terbimbing Berorientasi pada Motivasi Belajar Siswa. Jurnal Inkuiri. ISSN: 22527893, Vol 5, No. 1, 2016 (hal 85-94)

Susanto, A. 2013. Teori Belajar Pembelajaran di Sekolah Dasar. Jakarta: PT. Kharisma Putra Utama. Pembelajaran Program Pascasarjana Universitas Negeri Malang.

Tegeh,I M. 2008. Media Pembelajaran. Singaraja: Program Doktor Teknologi

Utami, D. L. 2017. Penyusunan Media Pembelajaran Video Animasi Sistem Saraf Untuk Meningkatkan Motivasi Belajar Siswa Kelas Xi Sma Negeri 1 Kasihan Bantul. Jurnal Prodi Pendidikan 40 Biologi Vol 6 No 2 tahun 2017 